\title{
The Role of Corporate Social Responsibility While Improving the Level of Personnel Security
}

\author{
E. V. Karanina*, V. M. Karaulov, A. N. Timin \\ Vyatka State University, Kirov, Russia \\ *Corresponding author. Email: karanina@vyatsu.ru
}

\begin{abstract}
The article presents research materials to test the hypothesis about the possibility of using corporate social responsibility as a tool for ensuring personnel security. The authors use a target approach as the starting point of the methodological substantiation of the assumption. According to this approach, tools are only those CSR measures and actions that ensure the prevention of threats to personnel security. Based on two approaches (meaningful and functional) to the content of personnel security, the authors of the research prove the fundamental importance of the threat category for the functioning of the personnel security system. It is necessary to study this issue due to the lack of scientific works on the coordination of activities in the field of CSR and personnel security. The authors systematize a list of appropriate CSR actions in the field of social and labor problems, proposed by scientists and specialists and regulated by regulatory enactments, and a list of threats to the interests of the company's employees. The article presents the results of comparing the corresponding actions of CSR and personnel threats, which make it possible to prove the hypothesis.
\end{abstract}

Keywords: corporate social responsibility, personnel security, threats, tools, appropriate actions.

\section{INTRODUCTION}

The central place of personnel security in the economic security system is determined by the role of labor potential in the company's activities. Therefore, many scientists and specialists conduct their research in the field of problematic issues of ensuring personnel security: I. Bogatyreva, N.V. Borovskikh, R.S. Esikova, L. Ilyukhina, O. A. Klindukhova, A. Ya. Kibanov, E.A. Kipervar, K.V. Lysak, A.O. Lysenko, I.N. Makhmudova, A.M. E.I. Morozova Mustafieva, I.I. Salnikov, L.T. Snitko, T.O. Solomandina, V.G. Solomandin, T.F. Tarasova, Redman, T., Wilkinson, A. Kontemporary, F.M Roka, Z. Guan, S. Urošević, B. Pejčić and others.

E.I. Ilyakova and O.S. Sausheva underline the importance of the actual level of labor and intellectual resources of the company, and social and labor relations in ensuring personnel security: "agreeing with the supporters of the resource approach, we propose to understand personnel security as the process of preventing negative impacts (damages) on the economic security of an enterprise at the expense of risks and threats associated with personnel, their intellectual potential and labor relations in general" [1]. But many scientists point out the dual role of the company's employees. On the one hand, they should be the object of personnel security, since the company may violate their rights and interests. On the other hand, as an active participant in all processes of the enterprise, an employee can violate interests of the company. In addition, as a rule, there is a conflict of interests between the company and its employee. It leads to various threats of personnel security and, as a consequence, tools to prevent them. It is the subject of research of N.V. Agramakova, Yu.V. Baramykina, N.V. Borovskikh, M.V. Varlamova, D.Sh. Gaidarbekova, A.V. Glushchenko, A.V. Dadalko, A.V. Ivashkina, D.V. Klimova, E.N. Kuznetsova, N.V. Kuznetsova, W.P. Lebedeva, E.A. Kippervar, E.P. Kucherova, N.V. Poddubnoi, A.I. Pisarevskaya, A.V. Semenchenko, T.O. Solomandina, V.G. Solomandina, Yu. Sui, A. Yu. Timofeeva and others.

Social processes, including social and labor relations with employees of organizations, are central in all regulations governing the procedure for companies to accept social responsibility and reporting on it [2]. Russian and foreign scientists study the issues of influencing company activities and its effectiveness of the adoption of corporate social responsibility: I.R. Badykov, V.P. Bardovsky, M.N. Vandyshev, E. A. Danilova, R. V. Dmitriev, S.E. Erypalov, A.D. Zaretsky, T.E. Ivanova, M.A. Izmailova, A.V. Kalina, O. Kanaeva, A. Kanaev, A.A. Konareva, A.E. Kostin, G.B. 
Kosharnaya, V.V. Krivorotov, K.M. Marakaeva, V.I. Maslov, V.R. Medvedeva, S.V. Myasnikova, E. Rashidin, E.V. Timoshkina, Kim Soojin, Krishna Arunima, Dhanesh Ganga L. Koep, S. Lee, Verčič Tkalac A., Ćorić Sinčić D., Wang R., Huang Y. However, they do not consider the integration of appropriate solutions into personnel security processes.

In this regard, the main purpose of this research is to substantiate the hypothesis about the possibility of using corporate social responsibility as a tool for ensuring personnel security.

In accordance with the purpose of the study, the main tasks are:

- $\quad$ to make a list of appropriate actions for interaction with company's employees in the framework of corporate social responsibility according to the Social Responsibility Guidelines;

- to compare threats to personnel security and corresponding actions in the framework of ensuring corporate social responsibility.

\section{MATERIALS AND METHODS}

The methodological basis of the study is the fundamental provisions of the theory of economic systems and economic security. The study is based on a logical analysis of the provisions of the National Standard of the Russian Federation "Guidelines for Social Responsibility" (GOST R ISO 26000-2012), scientific works in the field of corporate social responsibility and personnel security.

The authors use various methods while analyzing this issue, including abstract-logical, comparative analysis, systemic and situational approaches.

\section{RESULTS AND DISCUSSION}

Scientists and specialists use two approaches to the content of the concept "personnel security": substantive and functional. According to the first approach, personnel security is a state of the economic system at any level, when emerging dangers and threats in the sphere of social and labor relations do not lead to catastrophic risks, violating the interests of an economic entity, its employees and the state. According to the second approach, personnel security is a system that controls hazards, prevents threats in the sphere of social and labor relations and minimizes risks of violating the interests of an economic entity, its employees and the state. In any case, the subject of personnel security is threats to the interests of subjects entering into social and labor relations. That is why all studies in the field of ensuring personnel security also include issues about identification of threats. Having analyzed the results of these studies, we can conclude that there is no consensus either on the content of this category, or on the lists of threats to personnel security [3-6]. N.N. Karzayeva, on the basis of her approach to defining categories of danger, threat, risk, suggests a list of threats to personnel security $[5,6]$, which we use in our research.

According to the criterion of subjects (company, employee, state), threats can be divided into three groups:

- $\quad$ interests of a person (an employee of an enterprise or a resident of the region where the enterprise is located): threats to their life and health, various kinds of discrimination, inadequate compensation for labor, violation of social justice and deprivation of social benefits, etc.;

Table 1. The relationship between company actions while adopting corporate social responsibility and preventable threats to personnel security

\begin{tabular}{|c|l|l|}
\hline $\begin{array}{c}\text { Scope of } \\
\text { problems }\end{array}$ & \multicolumn{1}{|c|}{ Appropriate actions } & \multicolumn{1}{|c|}{ Threats to personnel security } \\
\hline $\begin{array}{c}\text { Economic, } \\
\text { social and } \\
\text { cultural } \\
\text { rights }\end{array}$ & facilitating access to education and traning for members of society & $\begin{array}{l}\text { - performing hazardous types of work by employees who do not have } \\
\text { a sufficient level of competence; } \\
\text { - inadequacy of qualifications for the position; } \\
\text { - low level of susceptibility of company employees to technical and } \\
\text { other innovations; } \\
\text { - low qualification of company employees }\end{array}$ \\
\hline $\begin{array}{c}\text { Fundamental } \\
\text { principles } \\
\text { and rights at } \\
\text { work }\end{array}$ & $\begin{array}{l}\text { - regular assessment of the impact of company policies and activities } \\
\text { on promoting equal opportunities and non-discrimination; } \\
\text { - organization of workplaces for people with disabilities; } \\
\text { - organization or participation in programs that promote the } \\
\text { employment of young and older workers, the provision of equal } \\
\text { conditions for women, a more balanced representation of women in } \\
\text { high positions }\end{array}$ & $\begin{array}{l}\text { - discrimination in the labor sphere (national, gender, age, religious, } \\
\text { etc.); }\end{array}$ \\
$\begin{array}{c}\text { - control over the legal registration of actual labor relations; } \\
\text { - use personnel in order to create permanent jobs; } \\
\text { - use measures to reduce the economic and social consequences of } \\
\text { the closure of the enterprise; } \\
\text { labor and } \\
\text { relations } \\
\text { - not to dismiss employees unreasonably or on discriminatory } \\
\text { grounds; } \\
\text { - protect personal data and confidentiality of workers }\end{array}$ & $\begin{array}{l}\text { - errors in planning human resources; } \\
\text { - violation of work and rest regimes; } \\
\text { - increased work intensity of the employee, exceeding the established } \\
\text { level; } \\
\text { - inciting employees to illegal actions and violation of obligations to } \\
\text { the employer (transfer of confidential information, forgery, etc.); } \\
\text { - transfer of confidential information by an employee of the } \\
\text { organization to third parties; } \\
\text { - discrimination in the labor sphere (national, gender, age, religious, } \\
\text { etc.); } \\
\text { - pressure, mobbing, bullying, harassment }\end{array}$ \\
\hline
\end{tabular}


Table 1. Continued.

\begin{tabular}{|c|c|}
\hline $\begin{array}{l}\text { Scope of } \\
\text { problems }\end{array}$ & Appropriate actions \\
\hline $\begin{array}{c}\text { Working } \\
\text { conditions and } \\
\text { social } \\
\text { protection }\end{array}$ & $\begin{array}{l}\text { - ensure the compliance of working conditions with the } \\
\text { requirements of laws and regulations; } \\
\text { - provide decent working conditions in terms of wages, } \\
\text { working hours, days off, holidays, labor protection and } \\
\text { safety at the workplace, maternity protection and the } \\
\text { ability to combine work with family responsibilities; } \\
\text { - if possible, allow the observance of national or religious } \\
\text { traditions and customs; } \\
\text { - provide wages and other forms of remuneration in } \\
\text { accordance with laws, regulations or collective } \\
\text { agreements; } \\
\text { - provide equal pay for work of equal value; } \\
\text { - fulfill all obligations to provide social protection to } \\
\text { workers; } \\
\text { - pay workers overtime as required by law, regulation or } \\
\text { collective agreement }\end{array}$ \\
\hline Safety at work & $\begin{array}{l}\text { - develop, implement and maintain safety policy at the } \\
\text { workplace; } \\
\text { - analyze and control risks associated with labor } \\
\text { protection and caused by the company activities; } \\
\text { - require compliance with appropriate procedures in } \\
\text { ensuring labor protection; } \\
\text { - provide safety equipment, including personal protective } \\
\text { equipment, necessary to prevent occupational injuries, } \\
\text { diseases and accidents, act in case of emergency } \\
\text { situations; } \\
\text { - document and investigate all incidents and problems } \\
\text { related to occupational safety, with the aim of minimizing } \\
\text { or eliminating them; } \\
\text { - eliminate psychosocial risks in the workplace that } \\
\text { contribute or lead to stress and illness }\end{array}$ \\
\hline $\begin{array}{c}\text { Staff } \\
\text { development } \\
\text { and on-the-job } \\
\text { training }\end{array}$ & $\begin{array}{l}\text { - provide employees with access to skills development, } \\
\text { training, apprenticeships, and career opportunities on an } \\
\text { equal and non-discriminatory basis; } \\
\text { - provide, if necessary, assistance to dismissed workers in } \\
\text { finding a new job, training; } \\
\text { - create programs that promote health and well-being }\end{array}$ \\
\hline
\end{tabular}

- interests of the company: threats to company's employees, as an integral part of the personnel potential of the company, persuading employees to commit unlawful actions and their commission, unprofessional and dishonest performance by the employee of official duties, unprofessional actions in the field of personnel activities;

- interests of the state: untimely and incomplete transfer of funds to the relevant budgets and offbudget social insurance funds, failure to provide social guarantees to company's employees.

Due to the large scale of the research area, this article only considers threats to the interests of the company's employees (Table). Understanding threats to human resources security is of fundamental importance for identifying mechanisms and tools to prevent them. The fundamental tool for regulating relations between an employee and an employer is personnel policy, which is a set of actions aimed to establish, maintain and terminate labor relations. Personnel policy should solve a whole range of tasks:

- $\quad$ to determine the needs for labor resources of the required quantity and quality;

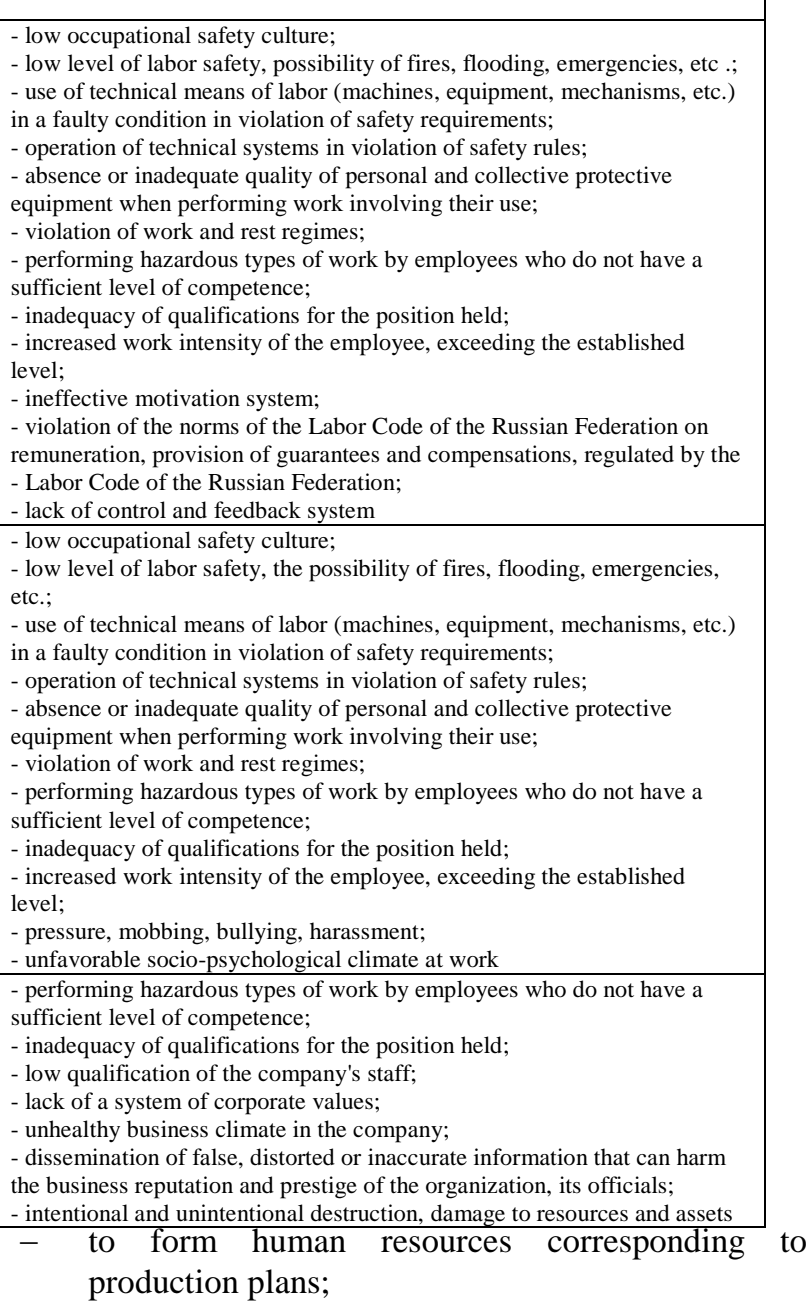

- to form requirements for the economic, material, social and psychological conditions of work;

- $\quad$ to form conditions for improving the professional competencies of each employee.

Obviously, the last three goals reflect the coincidence of the goals of the employer and the employee, which makes it possible to draw a conclusion about the implementation of the principles of corporate social responsibility (hereinafter - CSR), i.e. taking into account the interests of members of society when organizing the activities of the company. The principles of the conceptual framework of CSR, reflecting the relationship between the employer and the employee, include the observance of human rights and the prevention of their violations, the maintenance of the freedom of association and recognition of the rights of personnel to conclude collective agreements, the prevention of forced and child labor, discrimination in the sphere of labor and employment, prevention of environmental pollution, environment, anti-corruption $[1,7]$. 
Many researchers underline the role and importance of the social direction, including the relationship with the employees of the company, in the modern concept of CSR [8-12]. They offer various forms of implementing CSR principles in the social sphere, in particular:

- $\quad$ providing employees with safe working conditions $[13,14,19]$,

- $\quad$ providing effective jobs [13],

- providing comfortable social and living conditions at work [13];

- $\quad$ providing social benefits $[13,16,17,19]$,

- ensuring a decent level of wages and its timely payment, forming incomes of the population $[13,14,16,17,18,19]$

- implementing legislative norms and adopted collective agreements in the field of regulation of social and labor relations [13, 14, 19],

- comprehensive support for professional, personal, career growth and cultural development of employees [13,15,18],

- creating an atmosphere of mutual respect [14],

- forming corporate culture of personnel, spirit of teamwork and mutual assistance in the team, open communication in a team, teamwork, innovation, staff satisfaction [15],

- $\quad$ ensuring employment of the population [16],

- ensuring a safe environmental situation at the enterprise and in the settlement $[16,17,19]$,

- providing an opportunity to receive qualitative medical services $[16,17]$,

- supporting former employees of the enterprise $[16,17]$,

- $\quad$ supporting family members of employees [18],

- observing human rights provided by the Constitution of the Russian Federation [19].

E.V. Timoshkina suggests the following functions of corporate social responsibility: focusing on the unity of goals and needs of the company and its employees, instilling in employees feelings of identification with the company where they work, ensuring a higher level of social protection for employees in comparison with state guarantees, creating a favorable microclimate at work; creating a positive image of the company [20].

The measures proposed by regulatory enactments and specialists that implement the principles of CSR are aimed to fulfill by companies their obligations to employees and to create conditions when employees do not violate interests of the company. This allows us to make the assumption that the state of the economic system in the field of social and labor relations can be recognized safe when fulfilling these obligations. To verify this, it is necessary to compare the list of appropriate actions by areas of problems with threats to personnel security (Table). The comparison made clearly demonstrates the possibility of preventing threats to personnel security by carrying out these activities, and the tools for ensuring personnel security should include them.

\section{CONCLUSION}

The aggravation of social problems caused by the coronavirus infection pandemic, and the decrease in budgetary possibilities for financial support of many social programs have led to an increase in the importance of CSR. On the other hand, a risk-based approach to business involves the development of appropriate tools to ensure all types of economic security. In this regard, it is necessary to consider the possibilities of integrating these areas of entrepreneurial activity in order to optimize them.

The systematization and analysis of appropriate actions that ensure the implementation of the CSR principles proposed by scientists and specialists and regulated by regulatory enactments made it possible to make an assumption about the possibility of integrating CSR into the personnel security system.

Comparison of threats to personnel security and corresponding actions in the framework of CSR confirm the hypothesis about the possibility of using corporate social responsibility as a tool for ensuring personnel security.

\section{REFERENCES}

[1] I.E. Elyakova, O.S. Sausewa, Diagnosis of intellectual and personnel components of the economic security Corporation: threats and neutralization conditions. In: Internet-journal "science of SCIENCE", 7(5) (2015). http://naukovedenie.ru/PDF/221EVN515.pdf.

[2] Social responsibility guidelines national standard of the Russian Federation GOST R ISO 26000-2012. https://docs.cntd.ru/document/1200097847.

[3] E.V. Karanina, D. Loginov, Indicators of Economic Security of the Region: a Risk-Based Approach tu Assessing and Rating. In: IOP Conference Series: Materials Science and Engineering, 90(1) (2017) 012087.

[4] E.V. Karanina, O.A. Ryazanova, A.N. Timin, L.P. Domracheva, Diagnostigs and Monitoring of Economic entities Security. In: E3S Web of Conferences. 2018 Topical Problems of 
Architecture, Civil Engineering and Environmental Economics, 08002 (2018).

[5] N.N. Karzaeva, Методологические аспекты построения системы индикаторов кадровой безопасности хозяйствующего субъекта. In: Academy Bulletin, 2 (2019) pp. 62-74

[6] N.N. Karzaeva, L.V. Davydova, Methodological Approaches for Creating a System of Securiti Indicators for Company's Personnel. In: Utopía y Praxis Latinoamericana, 25(6) (2020) pp. 219-228

[7] A.D. Zaretsky, T.E. Ivanova, Corporate social responsibility: world and domestic practice. In: Economic Sciences, 12 (2011) pp. 91-93.

[8] V.I. Maslov, Strategic human resource management: teaching materials. In: Moscow, Berlin, Direct-Media, p. 156 (2017).

[9] V.R. Medvedeva, Corporate social responsibility in the management system of an organization. In: Bulletin of the Altai Academy of Economics and Law, 8 (2018) pp. 180-187

[10] Kim Soojin, Krishna Arunima, Dhanesh Ganga, Economics or ethics? Exploring the role of CSR expectations in explaining consumers' perceptions, motivations, and active communication behaviors about corporate misconduct. In: Public Relations Review, 45(1) (2019) pp. 76-87.

[11] Tkalac A.Verčič, D. Ćorić Sinčić, The relationship between reputation, employer branding and corporate social responsibility. In: Public Relations Review, 44(4) (2018) pp. 444-452.

[12] R. Wang, Y. Huang, Communicating corporate social responsibility (CSR) on social media. In: Corporate Communications: An International Journal, 23(3) (2018) pp. 326-341.

[13] M.A. Izmailova, Corporate social responsibility of Russian TNCs as a factor in the sustainable development of a global society. In: MIR (Modernization. Innovation. Development.), 4 (105) (2019) pp. 1242-1245

[14] V.V. Krivorotov, A.V. Kalina, S.E. Erypalov, Competitiveness of enterprises and production systems. In: Moscow, Unity-Dana, p. 351 (2015).

[15] V.P. Bardovsky, Corporate social responsibility in the system of organizational management. In: Education and Science Without Borders: Fundamental and Applied Research, 8 (1918) pp. 47-50.

[16] I.R. Badykova, Corporate social responsibility of city-forming enterprises as a factor in ensuring sustainable development of single-industry municipalities. In: Regional Economics and
Management: an electronic scientific journal, 3(59) (2019) pp. 14.

[17] M.N. Vandyshev, Modalities of social responsibility of town-forming enterprises in small towns. In: Culture, personality, society in the modern world: Methodology, experience of empirical research. XV International conference in memory of prof. L.N. Kogan, 2012, pp. 960-964, http://elar.urfu.ru/bitstream/10995/50650/1/978-58019-0294-4_2012_189.pdf.

[18] G.B. Kosharnaya, R.V. Dmitriev, Social responsibility of entrepreneurship in the regional society. In: Regionology, 25(2) (2017) pp. 294-305.

[19] A.E. Kostin, Corporate responsibility and sustainable development. In: Moscow, Institute for Sustainable Development of the Public Chamber of the Russian Federation, Center for Environmental Policy of Russia, p. 80 (2013).

[20] E.V. Timoshkina, Modern information technologies in personnel management and their place in the personnel policy of an organization. In: Economics and Entrepreneurship, 4-1(57-1) (2015) pp. 603-607 